\title{
Programmed cell death in Entamoeba histolytica induced by the aminoglycoside G418
}

\begin{abstract}
Correspondence
D. Guillermo Pérez Ishiwara

ishiwaramx@yahoo.com.mx
\end{abstract}

Received 11 April 2007

Revised 21 June 2007

Accepted 7 August 2007

\author{
J. D'Artagnan Villalba, ${ }^{1}$ Consuelo Gómez, ${ }^{1}$ Olivia Medel, ${ }^{1}$ \\ Virginia Sánchez, ${ }^{1,2}$ Julio C. Carrero, ${ }^{3}$ Mineko Shibayama ${ }^{4}$ \\ and D. Guillermo Pérez Ishiwara ${ }^{1}$ \\ ${ }^{1}$ Programa de Biomedicina Molecular ENMyH, Instituto Politécnico Nacional, CP 07320, Mexico \\ ${ }^{2}$ Escuela Militar de Graduados de Sanidad, UDEFA CP 11620, Mexico \\ ${ }^{3}$ Departamento de Inmunología, IIB, UNAM, Mexico \\ ${ }^{4}$ Departamento de Patología Experimental CINVESTAV-IPN, CP 07300, Mexico
}

\section{INTRODUCTION}

Entamoeba histolytica, the causal agent of amoebiasis, is a protozoan parasite that resides in the colon of infected humans. The invasive trophozoites adhere to mucus and epithelial cells, proliferate by binary fusion, and release proteolytic factors that destroy the intestinal mucosa, resulting in amoebic dysentery. In one in 10 patients with intestinal E. histolytica infection, the trophozoites migrate through the portal vein to the liver and give rise to amoebic abscesses, the main cause of death by this parasite (Espinosa-Cantellano \& Martínez-Palomo, 2000). The apoptosis of host cells such as macrophages induced by contact with E. histolytica trophozoites has been widely studied, and it is considered an important feature of the host-parasite relationship (Ragland et al., 1994; Berninghausen \& Leippe, 1997).

Programmed cell death (PCD) has been considered a critical mechanism of development, differentiation and control of cellular proliferation in metazoans. However, increasing evidence indicates that PCD is also present in

Abbreviations: BCECF, 2-,7-bis(2-carboxyethyl)-5-(and 6)-carboxyfluor-

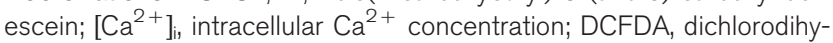
drofluorescein; $\mathrm{K}_{\mathrm{i}}^{+}$, intracellular potassium; NT, not (G418) treated; PBFI-AM, potassium-binding benzofuran isophthalate; PCD, programmed cell death; $\mathrm{pH}_{\mathrm{i}}$, intracellular $\mathrm{pH}$; PI, propidium iodide; PS, phosphatidylserine; ROS, reactive oxygen species; TUNEL, terminal deoxynucleotidyl transferase-mediated biotin-dUTP nick end labelling. unicellular organisms. Forms of PCD such as apoptosis, apoptosis-like processes and necrosis-like processes have been identified in several bacteria (Lewis, 2000), yeast (Madeo et al., 1999), the slime mould Dictyostelium discoideum (Cornillon et al., 1994), the dinoflagellate Peridinium gatunense (Vardi et al., 1999), the euglenoid Euglena gracilis (Scheuerlein et al., 1995), the ciliate Tetrahymena thermophila (Christensen et al., 1995), and the protozoan parasites Trypanosoma, Leishmania (Nguewa et al., 2004) and Plasmodium (Al-Olayan et al., 2002). Recently, results reported by Ramos et al. (2007) have suggested the induction of an apoptotic-like process by nitric oxide species in E. histolytica. Apoptosis is the result of a genetic program that induces cellular and biochemical changes, including caspase activation, externalization of phosphatidylserine (PS), an increase in intracellular $\mathrm{Ca}^{2+}$ and mitochondrial dysfunction, as well as physical changes such as cell shrinkage, alteration in cell volume, cytoplasmic blebbing and vacuolization, chromatin condensation, and nucleosomal fragmentation. Apoptosis is energy dependent, requiring ATP for signalling from the cytoplasm to the nucleus of the cell. The physiological role of apoptosis in protozoa is unknown. Although there is no obvious advantage at the individual level for unicellular organisms to carry the complex machinery required for PCD, the phenomenon has been related to altruistic behaviour, with clear benefits for the entire population, or as a mechanism to avoid host death (Wanderley et al., 
2005). Under conditions of limited nutrients or excessive expansion of the parasite population in the host, a subset of the population might 'commit suicide' by PCD.

Apoptosis, however, is not limited to physiological processes; it can also be induced by cellular damage such as treatment with antibiotics (Chen et al., 1995). G418 has been described as an apoptotic inducer in kidney cells, ear sensory hair cells and the Trypanosoma cruzi parasite. This drug is an aminoglycoside antibiotic used extensively for the treatment of human Gram-negative bacterial infections and in molecular biology research for the selection of prokaryotic and eukaryotic cells that have accepted neomycin-resistance genes. In kidney cells, G418-induced apoptosis is a caspase-dependent mechanism initiated by the release of cytochrome $c$ from mitochondria and the endoplasmic reticulum (Jin et al., 2004). Similarly, in ear sensory hair cells, G418-induced apoptosis is dependent on caspases activated by the phosphorylation of c-jun, the translocation of cytochrome $c$, and increased cytoplasmic calcium (Matsui et al., 2004). However, apoptosis in the protozoan parasite $T$. cruzi has been poorly studied. T. cruzi undergoes apoptosis in old cultures as well as in the presence of G418. Under both of these conditions, apoptosis is associated with the translocation from the cytosol to the nucleus of elongation factor 1 , a protein involved in eukaryotic protein biosynthesis (Billaut-Mulot et al., 1996). The role of elongation factor 1 in apoptosis is unknown, but it has been suggested to be involved in transcriptional processes.

The present study is believed to be the first to report PCD in trophozoites of the human intestinal parasite $E$. histolytica exposed to the antibiotic G418. PCD features that were determined in G418-treated trophozoites include nuclear staining by terminal deoxynucleotidyl transferasemediated biotin-dUTP nick end labelling (TUNEL), DNA fragmentation and compaction, production of reactive oxygen species (ROS), potassium release, increased cytoplasmic calcium, acidification of intracellular $\mathrm{pH}\left(\mathrm{pH}_{\mathrm{i}}\right)$, and decreased cellular volume. Our results suggest that amoebae can undergo PCD under stress conditions such as treatment with G418. The possible significance of this phenomenon in the host-amoeba relationship is discussed.

\section{METHODS}

Parasite and growth conditions. Trophozoites of clone A (strain HM1:IMSS) were cultured axenically in TYI-S-33 medium (Diamond et al., 1978). PCD was induced in trophozoites by incubation with $10 \mu \mathrm{g} \mathrm{G} 418 \mathrm{ml}^{-1}$ for different periods of time, as indicated.

Kinetics of growth. Growth curves of trophozoites were determined in the absence (not treated; NT) or presence of $10 \mu \mathrm{g} \mathrm{G} 418 \mathrm{ml}^{-1}$. Trophozoite viability was measured every $12 \mathrm{~h}$ by using Trypan Blue exclusion.

Flow-cytometry assays and microscopic analysis. Changes in size and in the light-scattering properties of trophozoites were determined by flow cytometry, as described by Hawley et al. (2004), using a Becton Dickinson FACSCalibur equipped with CellQuest software (Becton Dickinson). Trophozoites $\left(1 \times 10^{6}\right)$, non-treated or treated with $10 \mu \mathrm{g} \mathrm{G} 418 \mathrm{ml}^{-1}$, were analysed using a $488 \mathrm{~nm}$ argon laser. A specific gate based on the properties of control trophozoites was selected to determine their positions on a forward scatter vs side scatter dot plot. Light scattered in the forward direction is roughly proportional to cell size, whereas light scattered at a $90^{\circ}$ angle (side scatter) is proportional to cell density. For microscopic analysis, G418-treated or NT trophozoites were washed twice with PBS and placed on glass slides. Trophozoites were fixed in $2 \%$ formaldehyde and observed using an Olympus BX41 inverted microscope coupled to a Media Cybernetics CoolSNAP-Pro digital video camera with Image-Pro Plus software.

Effect of cysteine protease inhibitor E-64. Ten-thousand trophozoites were cultured in TYI-S-33 medium in the presence of 20 or $50 \mu \mathrm{M}$ E-64 [trans-epoxysuccinyl-L-leucylamido (4-guanidino) butane; Sigma Aldrich] or without the drug. One hour later, trophozoites were induced to PCD by co-incubation with $10 \mu \mathrm{g}$ G418 $\mathrm{ml}^{-1}$ for $6 \mathrm{~h}$. Finally, DNA electrophoresis, TUNEL and transmission electron microscopy assays (described below) were conducted.

Nuclear extracts and DNA isolation. Nuclei from G418-treated, G418-treated co-incubated with E-64, or NT trophozoites were obtained as reported by Gómez et al. (1998), with some modifications. Briefly, $1 \times 10^{6}$ trophozoites were washed twice with PBS, $\mathrm{pH} 6.8$, resuspended in four volumes of buffer A (0.01 M HEPES, $\mathrm{pH} 7.9,0.0015 \mathrm{M} \mathrm{MgCl}_{2}, 0.01 \mathrm{M} \mathrm{KCl}, 0.01 \mathrm{M}$ DTT, $0.0005 \mathrm{M}$ PMSF), and incubated on ice for $35 \mathrm{~min}$. The trophozoites were homogenized with 25 strokes in an all-glass Dounce homogenizer and centrifuged at 6000 r.p.m. at $4{ }^{\circ} \mathrm{C}$ for $10 \mathrm{~min}$. Integrity of the nuclei was monitored by phase-contrast microscopy. To isolate DNA from nuclei, the nuclear pellet was mixed with $750 \mu \mathrm{l}$ extraction buffer (0.02 M EDTA, 0.01M Tris, $0.5 \%$ SDS) containing $50 \mu \mathrm{g}$ proteinase $\mathrm{K} \mathrm{ml}^{-1}$ and incubated at $65{ }^{\circ} \mathrm{C}$ for $20 \mathrm{~min}$. Then, DNA was extracted with phenol/chloroform/isoamyl alcohol (25:24:1). Nucleic acids from G418-treated, NT and co-incubated with E-64 trophozoites were precipitated at $-20{ }^{\circ} \mathrm{C}$ by addition of $0.2 \mathrm{M} \mathrm{NaCl}$ and one volume of isopropyl alcohol. DNA was analysed by $2.0 \%$ agarose gel elecrophoresis at $100 \mathrm{~V}$ for $45 \mathrm{~min}$ and stained with $0.5 \mu \mathrm{g}$ ethidium bromide $\mathrm{ml}^{-1}$.

Nick-labelling of internucleosomal DNA fragments. Ten-thousand G418-treated, G418-treated co-incubated with E-64, or NT trophozoites were fixed in $4 \%$ formaldehyde for $45 \mathrm{~min}$ at $4{ }^{\circ} \mathrm{C}$. After washing twice with PBS, $50 \mu \mathrm{l}$ TUNEL reaction mixture (Roche) was added and incubated for $60 \mathrm{~min}$ at $37{ }^{\circ} \mathrm{C}$ in a humidified atmosphere in the dark. Trophozoites were rinsed three times with PBS, loaded on slides, and observed with a Zeiss LSM Pascal confocal microscope. As a positive control, trophozoites were treated with $20 \mu \mathrm{g} \mu \mathrm{l}^{-1}$ DNase I endonuclease for $10 \mathrm{~min}$.

Transmission electron microscopy analysis. Trophozoites grown in the absence or presence of $10 \mu \mathrm{g} \mathrm{G} 418 \mathrm{ml}^{-1}$ were harvested after 3, 6, 9 and $12 \mathrm{~h}$ of incubation. Trophozoites co-incubated with E-64 were harvested after $9 \mathrm{~h}$ of incubation. Trophozoites were washed twice with $0.1 \mathrm{M}$ sodium cacodylate buffer and fixed for $1 \mathrm{~h}$ with $2.5 \%$ glutaraldehyde in $0.1 \mathrm{M}$ sodium cacodylate buffer, $\mathrm{pH}$ 7.4. Fixed trophozoites were washed twice with $0.1 \mathrm{M}$ sodium cacodylate buffer, post-fixed with $2.0 \%$ osmium tetroxide, dehydrated with ethanol at increasing concentrations, and treated with propylene oxide. The trophozoites were then embedded in epoxy resins. Semithin sections were stained with toluidine blue for light-microscopic examination. Thin sections were stained with uranyl acetate followed 
by lead citrate, and examined with a Zeiss EM-10 electron microscope.

Detection of PS. PS externalization was assessed by monitoring annexin V-FITC binding in viable cells. Briefly, $1 \times 10^{6} \mathrm{G} 418$-treated or NT trophozoites were resuspended in $500 \mu \mathrm{l} 1 \times$ binding buffer (Apoptosis Detection kit, BioVision) containing annexin V-FITC and propidium iodide (PI). After $10 \mathrm{~min}$ of incubation in the dark, trophozoites were washed twice with fresh binding buffer. Annexin V-FITC-stained trophozoites were detected by flow cytometry (excitation wavelength, $488 \mathrm{~nm}$; emission wavelength, $530 \mathrm{~nm}$ ) using an FITC signal detector (FL1), and PI staining was detected by the phycoerythrin emission signal detector (FL2). Alternatively, staining of trophozoite membranes was visualized by confocal microscopy using a Zeiss LSM Pascal confocal microscope.

Measurement of ROS. To determine the levels of ROS, the cellpermeant probe dichlorodihydrofluorescein (DCFDA; Sigma Aldrich) was used. In the presence of a suitable oxidant, DCFDA is oxidized to the highly fluorescent 2,7-dichlorofluorescein. NT or G418-treated trophozoites $\left(1 \times 10^{6}\right)$ were resuspended in $500 \mu$ phosphate buffer, $\mathrm{pH} 7.4$, containing $0.02 \mathrm{M}$ DCFDA, incubated in the dark for $15 \mathrm{~min}$, and analysed by flow cytometry (excitation wavelength, $485 \mathrm{~nm}$; emission wavelength, $525 \mathrm{~nm}$ ) using the CellQuest software.

Measurement of intracellular potassium $\left(\mathbf{K}_{\mathbf{i}}^{+}\right)$levels. $\mathrm{K}_{i}^{+}$levels were determined by using $5 \mu \mathrm{M}$ potassium-binding benzofuran isophthalate (PBFI-AM; Sigma Aldrich) as a cell-permeant probe and a FACSCalibur flow cytometer. Briefly, $1 \times 10^{6}$ trophozoites were grown in the presence or absence of $10 \mu \mathrm{g} \mathrm{G} 418 \mathrm{ml}^{-1}$ for $6 \mathrm{~h}$, harvested, and washed twice with a buffer containing $0.116 \mathrm{M} \mathrm{NaCl}$, $0.0054 \mathrm{M} \mathrm{KCl}, 0.0008 \mathrm{M} \mathrm{MgCl}_{2}, 0.0055 \mathrm{M}$ glucose and $0.05 \mathrm{M}$ MOPS, pH 7.4. Trophozoites were resuspended in the same buffer and incubated with PBFI-AM for $1 \mathrm{~h}$ at $37^{\circ} \mathrm{C}$. Then, the trophozoites were pelleted at 1500 r.p.m. for 2 min. After two washing steps, trophozoites were resuspended in fresh buffer. Prior to flowcytometric analysis, PI was added to each sample to a final concentration of $10 \mu \mathrm{g} \mathrm{ml}^{-1}$. Ten-thousand trophozoites were analysed by excitation at 370 and $488 \mathrm{~nm}$ for PBFI-AM and PI, respectively, and emission was registered at $540 \mathrm{~nm}$.

Cytosolic $\mathrm{Ca}^{2+}$ concentrations. Changes in intracellular $\mathrm{Ca}^{2+}$ concentration $\left(\left[\mathrm{Ca}^{2+}\right]_{\mathrm{i}}\right)$ were monitored with the fluorescent probe Fura-2/AM. After harvesting, trophozoites were washed twice at 1500 r.p.m. for $2 \mathrm{~min}$ at $4{ }^{\circ} \mathrm{C}$ in buffer I, which contained $0.116 \mathrm{M}$ $\mathrm{NaCl}, 0.0054 \mathrm{M} \mathrm{KCl}, 0.0008 \mathrm{M} \mathrm{MgSO}_{4}, 0.0055 \mathrm{M} \mathrm{D}$-glucose and $0.05 \mathrm{M}$ HEPES, pH 7.0. Amoebae were resuspended in loading buffer $\left(1 \times 10^{6}\right.$ trophozoites $\left.\mathrm{ml}^{-1}\right)$ that contained $0.116 \mathrm{M} \mathrm{NaCl}, 0.0054 \mathrm{M}$ $\mathrm{KCl}, 0.0008 \mathrm{M} \mathrm{MgSO}_{4}, 0.0055 \mathrm{M}$ D-glucose, $1.5 \%$ sucrose, $0.05 \mathrm{M}$ HEPES, $\mathrm{pH} 7.4$, and $6 \mu \mathrm{M}$ Fura-2/AM. The trophozoite suspension was incubated for $1 \mathrm{~h}$ at $37^{\circ} \mathrm{C}$ with occasional agitation. Then, trophozoites were washed four times with ice-cold buffer I to remove extracellular dye. For fluorescence measurements, $125 \mu \mathrm{l}$ of the trophozoite suspension was diluted into $2.4 \mathrm{ml}$ buffer I. Fura-2/AM was excited at $340 \mathrm{~nm}$, and emission at $510 \mathrm{~nm}$ was registered by a Perkin Elmer MPF44A fluorimeter. The $\left[\mathrm{Ca}^{2+}\right]_{\mathrm{i}}$ in $\mathrm{nM}$ was determined at $30{ }^{\circ} \mathrm{C}$ using the formula:

$\left[\mathrm{Ca}^{2+}\right]_{\mathrm{i}}=K_{\mathrm{d}} \times \frac{\left(F_{2}-F_{3}\right)}{\left(F_{4}-F_{1}\right)}$

where $F_{1}$ is the fluorescence signal obtained from the entire cell, $F_{2}$ represents the fluorescence signal after addition of $0.001 \mathrm{M} \mathrm{EGTA}, F_{3}$ is the fluorescence following cell lysis with $0.04 \%$ Triton X-100 in $0.03 \mathrm{M}$ Trizma base, and $F_{4}$ is the fluorescence after adding $0.004 \mathrm{M}$ $\mathrm{CaCl}_{2} . K_{\mathrm{d}}$ represents the dissociation constant value of $224 \mathrm{nM}$, as reported by Grynkiewicz et al. (1985). $\mathbf{p H}_{\mathbf{i}}$ measurements. Trophozoites $\left(1 \times 10^{6}\right)$ were resuspended in TYI-S-33 medium and washed twice with buffer A $(0.14 \mathrm{M} \mathrm{KCl}$, $0.004 \mathrm{M} \mathrm{CaCl}_{2}, 0.025 \mathrm{M}$ HEPES-Tris, pH 7.4). Then, trophozoites were loaded with $10 \mu \mathrm{M}$ 2-,7-bis(2-carboxyethyl)-5-(and 6)-carboxyfluorescein (BCECF; Sigma Aldrich) for $45 \mathrm{~min}$ in $1 \mathrm{ml}$ buffer A. Nigericin $\left(1 \mu \mathrm{g} \mathrm{ml}^{-1}\right)$ was added to the loading incubation. After loading, trophozoites were washed twice with buffer and resuspended in fresh buffer. Fluorescence was registered at $535 \mathrm{~nm}$ in a Perkin Elmer MPF44A fluorimeter. At the end of each experiment, an in situ $\mathrm{pH}$ calibration procedure with nigericin was used to relate the fluorescence intensities at $485 \mathrm{~nm}$ to the $\mathrm{pH}$ value. When cells are exposed to depolarizing high- $\mathrm{K}^{+}$buffers of different $\mathrm{pH}$ values ( $\mathrm{pH}$ 5.7-7.7), nigericin, an $\mathrm{H}^{+}-\mathrm{K}^{+}$exchanger ionophore, sets $\left[\mathrm{K}^{+}\right]_{\mathrm{o}}=\left[\mathrm{K}^{+}\right]_{\mathrm{i}}$ and $\mathrm{pH}_{\mathrm{o}}=\mathrm{pH}_{\mathrm{i}}$, where $\left[\mathrm{K}^{+}\right]_{\mathrm{o}}$ is extracellular potassium concentration, $\left[\mathrm{K}^{+}\right]_{\mathrm{i}}$ is intracellular potassium concentration, and $\mathrm{pH}_{\mathrm{o}}$ is extracellular $\mathrm{pH}$.

\section{RESULTS}

\section{Cytotoxic effect of G418 on E. histolytica trophozoites}

The effect of G418 on trophozoite viability was assessed by Trypan Blue exclusion staining. Compared with control NT trophozoites, $70 \%$ of trophozoites had died after $48 \mathrm{~h}$ of incubation with $10 \mu \mathrm{g} \mathrm{G} 418 \mathrm{ml}^{-1}$ (Fig. 1a). Morphological changes in G418-treated trophozoites were observed by light microscopy. Whereas NT parasites had typical amoebic forms, trophozoites exposed to G418 showed rounded forms and cell shrinkage (Fig. 1b). Moreover, the mean volume of G418-treated trophozoites was significantly lower than that of NT trophozoites.

\section{Changes induced by G418 in cell size and granularity}

To determine whether G418 induces trophozoite shrinkage, cell size was measured by the decrease in forward scatter in flow-cytometry analysis. As shown in Fig. 1(c), the trophozoite population treated with G418 showed a marked reduction in cell size. Whereas the sizes of $51.3 \%$ of NT trophozoites were greater than the mean value, G418-treated trophozoites had obviously diminished sizes, with only $16.9 \%$ of the total population having sizes greater than the mean $y$ axis value taken from the R1 population (Fig. 1c). Interestingly, changes in granularity were also observed by the increase in side scatter, from $13 \%$ in NT trophozoites to $50.1 \%$ in G418-treated parasites. These morphological changes resemble those observed during PCD. Accordingly, the biochemical changes induced by G418 were studied to explore a putative PCD process in this parasite.

\section{G418 induces DNA fragmentation in E. histolytica}

In mammalian cells, internucleosomal DNA fragmentation is one of the most important and typical nuclear features that define the PCD phenomenon (Collins et al., 1992). When electrophoresed on an agarose gel, nuclear DNA 
(a)

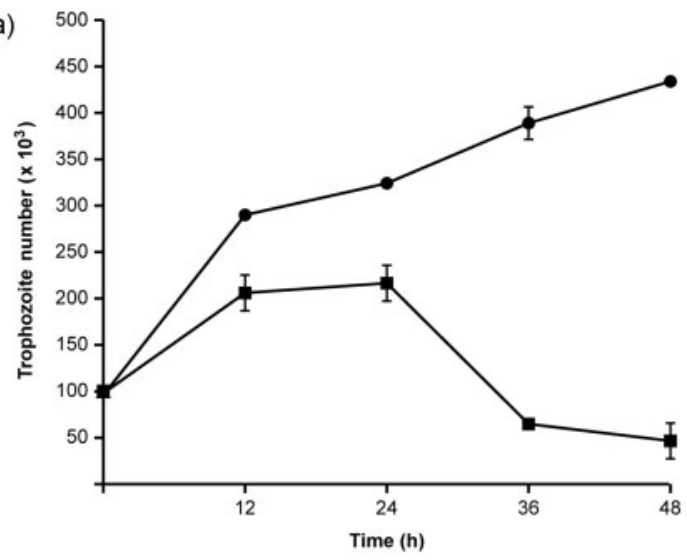

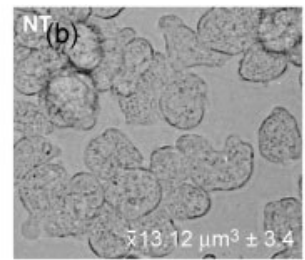

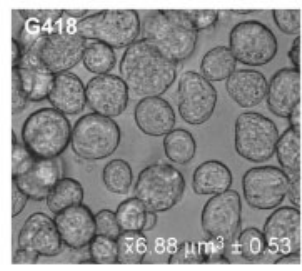

(c)
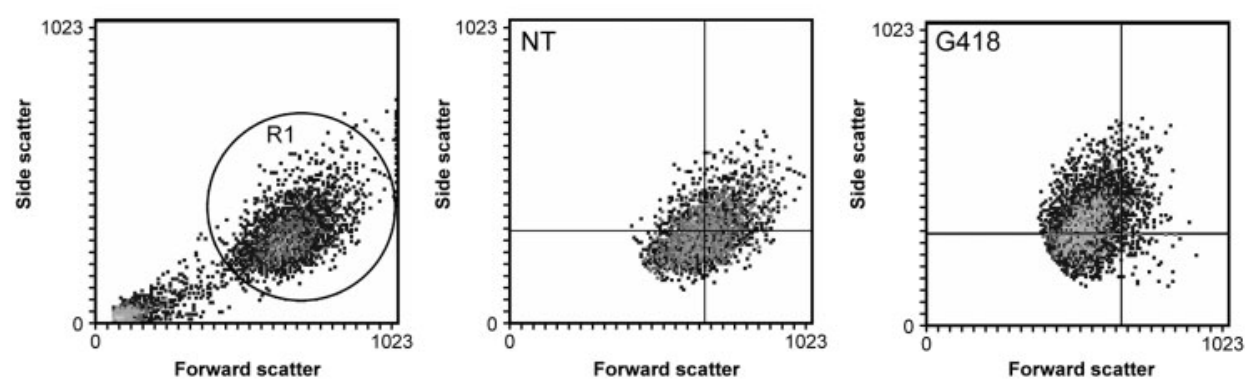

Fig. 1. Effects of the G418 antibiotic on the viability and morphology of E. histolytica trophozoites. (a) Growth kinetics of trophozoites cultured in the absence $(\bullet)$ or presence $(\boldsymbol{G})$ of $10 \mu \mathrm{g} \mathrm{G} 418 \mathrm{ml}^{-1}$. Viability was evaluated by Trypan Blue exclusion. (b) Phase-contrast micrographs showing the morphologies of NT and G418-treated trophozoites. The mean volumes (in $\mu \mathrm{m}^{3}$ ) of trophozoites were determined in triplicate. (c) Representative flow-cytometry plots indicating cell size (forward scatter) and granularity (side scatter) of NT and G418-treated trophozoites. The circle R1 drawn within the plot represents the gate of the 'viable' trophozoite population selected for the experiments.

from trophozoites treated with $10 \mu \mathrm{g} \mathrm{G} 418 \mathrm{ml}^{-1}$ appeared to be degraded (Fig 2a, lane 3, b, lane 2), whereas NT trophozoite DNA did not (Fig. 2a, lane 2). No obvious ladder pattern was detected for G418-treated trophozoite DNA; instead, five or six smeared DNA bands were observed. To confirm nuclear DNA fragmentation, TUNEL assays were conducted. Less than $10 \%$ of nuclei of NT trophozoites were stained (Fig. 2c). In contrast, $70 \%$ of trophozoites showed positive nuclear staining after $6 \mathrm{~h}$ of G418 incubation. As a positive control, trophozoites were incubated with DNase I endonuclease, and a negative staining control is also shown.

\section{Effect of E-64 on PCD induced by G418}

Incubation of parasites with the E-64 inhibitor abolished DNA fragmentation induced by G418. As shown in Fig. 2(b), lanes 3 and 4, the co-incubation of trophozoites with 50 and $20 \mu \mathrm{M}$, respectively, of E-64 inhibited DNA fragmentation, and DNA degradation almost disappeared, especially with the higher E-64 concentration used. Instead, a high-molecular-mass DNA band was observed, similar to that observed with the NT trophozoites (Fig. 2a, lane 2).
TUNEL assays of trophozoites treated with the E-64 inhibitor also showed a remarkable reduction in nuclear staining, so that less than $15 \%$ of trophozoite nuclei were stained (Fig. 2c).

\section{Transmission electron microscopy analysis}

By transmission electron microscopy, it was observed that G418 altered the typical morphology of E. histolytica nuclei. After $3 \mathrm{~h}$ of incubation with G418, trophozoites did not show any morphological differences from the control. Cell size was normal, with abundant vacuoles and glycogen deposits in the cytoplasm. The nucleus had dense peripheral chromatin with a central 'endosome'. The nuclear and plasma membranes appeared intact (Fig. 2d). After $9 \mathrm{~h}$ of incubation with G418, a different distribution of fragmented chromatin was observed, with the chromatin displaced to one side of the amoeba nucleus. The cytoplasm contained large vacuoles, and the amount of glycogen was increased. The nucleus was smaller than in NT trophozoites. After $12 \mathrm{~h}$ of G418 incubation, a smaller nucleus containing fragmented, dense chromatin was observed, and the round nuclear bodies were more 

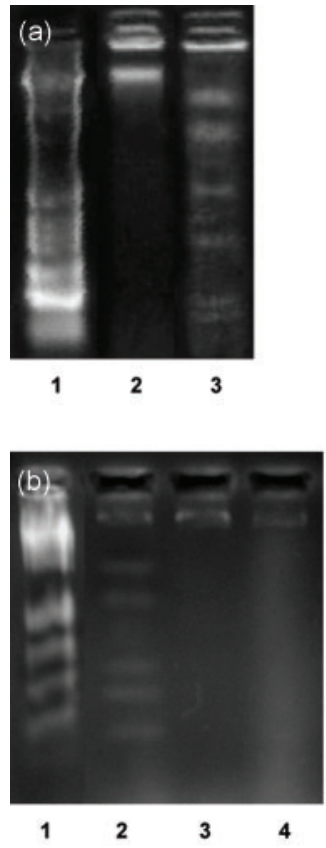
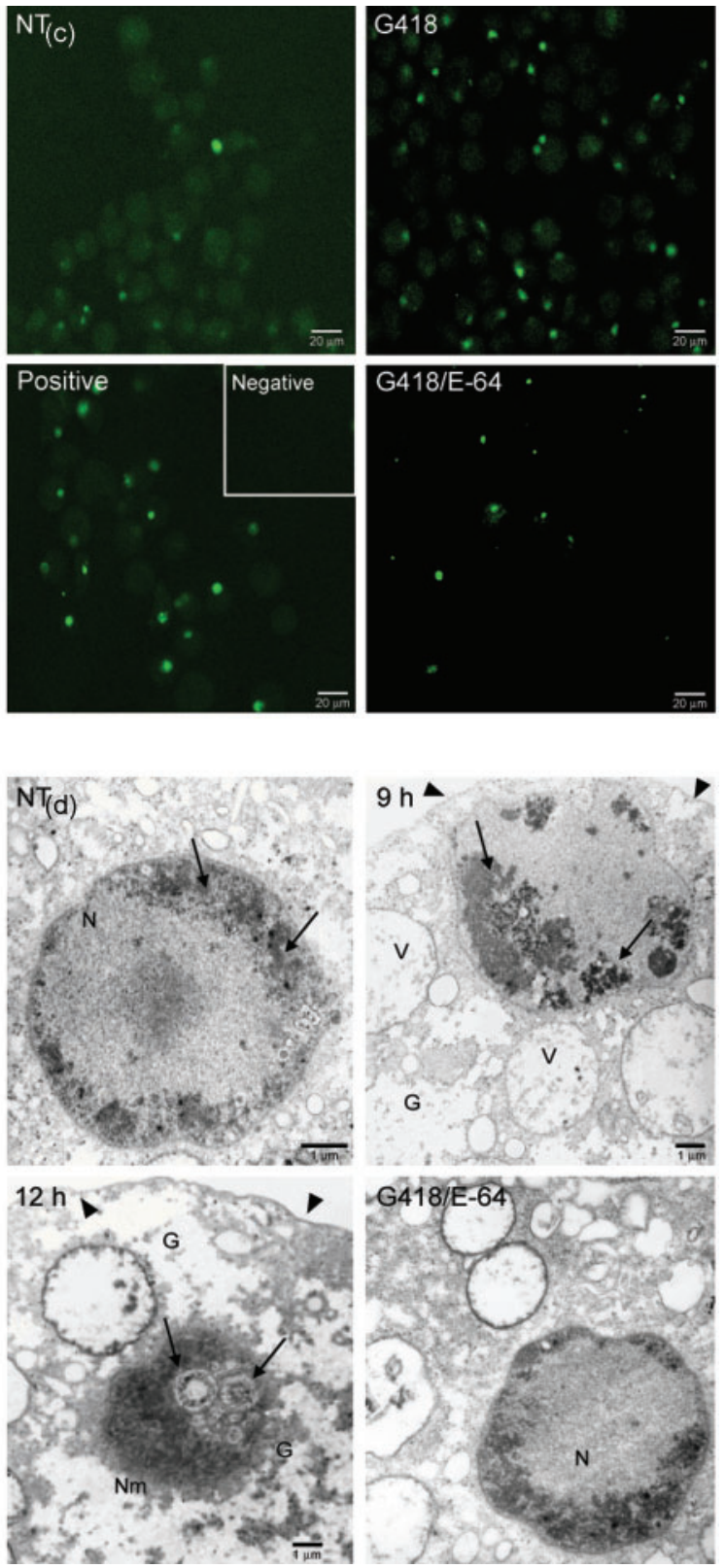

Fig. 2. DNA fragmentation and ultrastructural changes in trophozoites after G418 and E-64 treatments. (a) Agarose gel electrophoresis analysis of DNA. Lanes: 1, M 1000 DNA marker; 2, DNA from NT trophozoites; 3, DNA from G418-treated trophozoites. (b) Agarose gel electrophoresis analysis of DNA from trophozoites treated with E-64. Lanes: 1, $M_{r}$ DNA marker; 2 , DNA from G418-treated trophozoites; 3 and 4, DNA from trophozoites co-incubated with G418 and 50 and $20 \mu \mathrm{M}$ E-64, respectively. (c) Confocal microscopy analysis showing nuclear TUNEL staining of trophozoites after $6 \mathrm{~h}$ of incubation with G418, G418/E-64, and in NT trophozoites. As a positive control, trophozoites were treated with $20 \mu \mathrm{g} D$ ase I $\mu \mathrm{I}^{-1}$ and negative staining is also shown. Bars, $20 \mu \mathrm{m}$. (d) Ultrastructure of trophozoites after G418 and G418/E-64 treatments. A healthy NT trophozoite displaying a round nucleus $(\mathrm{N})$ and dense peripheral chromatin (arrows) is shown in the upper-left panel; a central endosome is also seen. The upper-right panel shows the ultrastructure after $9 \mathrm{~h}$ of $\mathrm{G} 418$ treatment. Clumps of chromatin have gathered mainly at one side of the nuclear envelope (arrows). The cytoplasm contains large clear vacuoles (V) and areas of glycogen $(\mathrm{G})$. The lower-left panel shows the ultrastructure after $12 \mathrm{~h}$ of incubation with $\mathrm{G} 418$. A condensed nucleus is occupied by dense chromatin, with loss of the nuclear membrane $(\mathrm{Nm})$. Round, dense nuclear bodies are conspicuous (arrows). Irregular, clear areas that correspond to glycogen are abundant (G). The plasma membranes in all trophozoites appeared intact (arrowheads). Bars, $1 \mu \mathrm{m}$. The lower-right panel shows the ultrastructure after $9 \mathrm{~h}$ of coincubation with G418 and $50 \mu \mathrm{M} \mathrm{E-64.} \mathrm{A} \mathrm{central} \mathrm{endosome} \mathrm{is} \mathrm{seen} \mathrm{with} \mathrm{a} \mathrm{round} \mathrm{nucleus}(\mathrm{N})$ and dense peripheral chromatin. No DNA lesions were observed. 


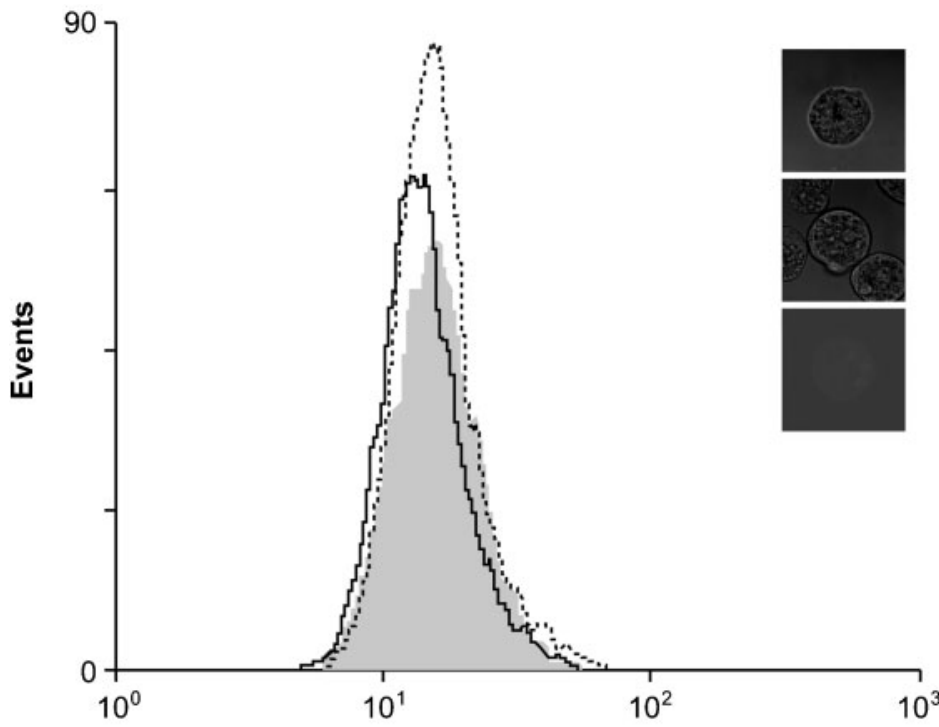

Annexin V-FITC intensity
Fig. 3. Detection of PS by annexin V-FITC. The graph shows representative flow-cytometry dot plots of PS detection in untreated (dashed line) and G418-treated trophozoites (continuous line) after $6 \mathrm{~h}$ of incubation. The shaded histogram peak represents the negative control fluorescence. Right-hand panels, confocal microscopy analysis showing PS detection in non-permeabilized (upper panel) and permeabilized (centre panel) trophozoites. An autofluorescence control is shown (lower panel). conspicuous. The outer limits of the nuclear envelope were not clearly defined. Cytoplasmic glycogen was increased significantly, and the number and size of vacuoles decreased substantially. For all times of incubation studied, cytoplasmic membranes appeared normal. In trophozoites co-incubated with G418 and $50 \mu \mathrm{M} \mathrm{E-64,} \mathrm{the} \mathrm{cell} \mathrm{size} \mathrm{and}$ nucleus appeared normal. As in the control trophozoites, the nucleus had dense peripheral chromatin, and no obvious DNA lesion was observed.

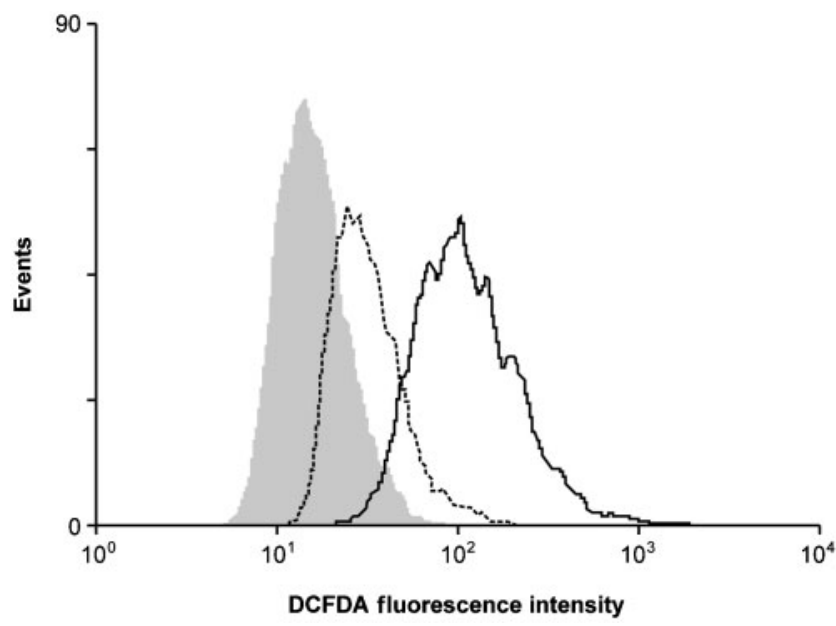

Fig. 4. Detection of ROS. ROS in NT (dashed line) or G418treated (continuous line) trophozoites were measured by flow cytometry using the fluorescent dye DCFDA. The shaded histogram peak represents the negative control fluorescence.

\section{G418 does not produce detectable changes in PS externalization}

During the early stages of typical PCD, translocation of PS from the inner to the outer layer of the plasma membrane occurs. To look for this phenomenon in G418-treated amoebae, we used flow cytometry and annexin V-FITC, which binds with high affinity to PS. No positive fluorescence was detected after incubation of trophozoites with G418 (Fig. 3). Aley and co-workers (Aley et al., 1980) reported that PS forms less than $10 \%$ of E. histolytica trophozoite membrane lipids. Thus, we searched for PS by confocal microscopy in permeabilized and unpermeabilized trophozoites. As shown in Fig. 3, no fluorescence signal was observed in the outer or inner plasma membrane. This result suggests that either annexin $\mathrm{V}$ is unable to recognize E. histolytica PS, or PS is not a component of the E. histolytica plasma membrane. As an internal control, PS was detected in apoptotic lymphocytes (data not shown).

\section{G418 induces oxidative stress in E. histolytica trophozoites}

Because the generation of intracellular ROS is associated with PCD, we analysed the production of ROS in G418treated trophozoites by flow cytometry, determining the conversion of DCFDA to the highly fluorescent 2,7dichlorofluorescein in the presence of a suitable oxidant. As shown in Fig. 4, NT trophozoites displayed ROS signals near to the control histogram peak, whereas G418-treated trophozoites exhibited substantial enhancement of ROS production: $62 \%$ of the trophozoite population showed 10 -fold increased fluorescence compared with the NT trophozoites. 


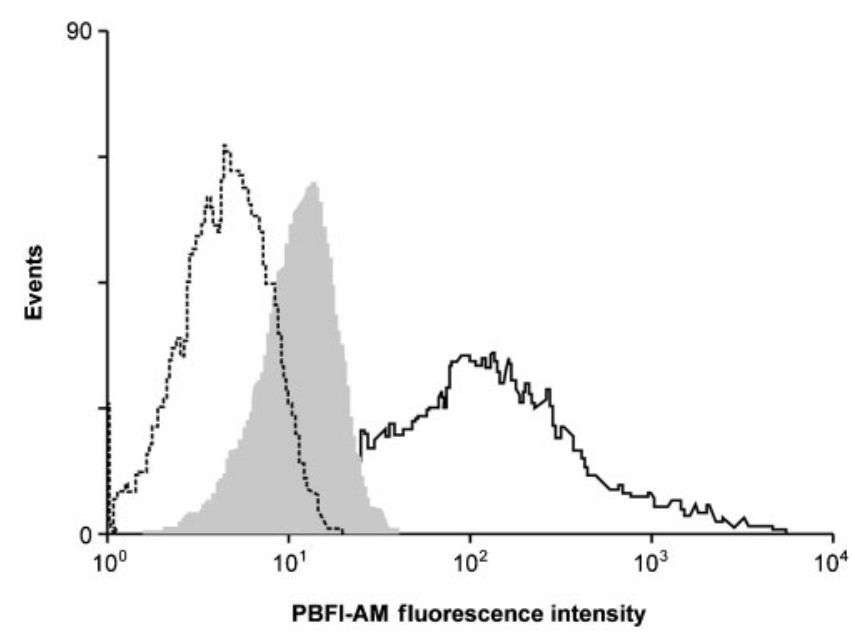

Fig. 5. Reduction in $\mathrm{K}_{\mathrm{i}}^{+}$levels during PCD. $\mathrm{K}^{+}$levels in $\mathrm{NT}$ (continuous line) or G418-treated (dashed line) trophozoites were measured by flow cytometry using the fluorescent dye PBFI-AM. The shaded histogram peak represents the negative control fluorescence.

\section{G418 induces changes in trophozoite $K_{i}^{+}$levels}

Overproduction of ROS inactivates the $\mathrm{Na}^{+}-\mathrm{K}^{+}$ATPase pump, decreasing the $\mathrm{K}_{\mathrm{i}}^{+}$level (Sen et al., 2004a). Thus, extrusion of $\mathrm{K}^{+}$ions and the subsequent loss of cell volume are among the most notable events of typical PCD. By using PBFI-AM fluorescent dye, the trophozoite $\mathrm{K}_{\mathrm{i}}^{+}$ concentration was analysed after G418 treatment. Without G418 treatment, $100 \%$ of trophozoites had a strong fluorescence signal, reflecting intracellular pools of $\mathrm{K}^{+}$. After G418 treatment, the intensity of fluorescence decreased by two orders of magnitude, evidencing a substantial loss of potassium (Fig. 5). Based on data published elsewhere (Sen et al., 2004b), it appears that impairment of the $\mathrm{Na}^{+}-\mathrm{K}^{+}$ATPase pump is a consequence of high ROS levels inside the cell and of lipid peroxidation.

\section{G418 increases trophozoite cytosolic $\mathrm{Ca}^{2+}$ levels}

Many studies have shown that calcium flux is required for the activation of several apoptotic mechanisms (Tandogan \& Ulusu, 2005). The increase in intracellular $\mathrm{Ca}^{2+}$ after G418 treatment was measured during a period of $120 \mathrm{~min}$ by spectrofluorometric analysis. The $\left[\mathrm{Ca}^{2+}\right]_{\mathrm{i}}$ of $\mathrm{NT}$ trophozoites remained stable $\left(20 \mathrm{nM} \mathrm{Ca}^{2+}\right)$ over the time period. However, in parasites treated with G418, the $\mathrm{Ca}^{2+}$ concentration increased from $20 \mathrm{nM}$ at the beginning to $44 \mathrm{nM}$ at $80 \mathrm{~min}$, with a maximum of $48 \mathrm{nM} \mathrm{Ca}^{2+}$ at 120 min of incubation with G418 (Fig. 6). The chelator EGTA was used as a control. As expected, EGTA greatly diminished the intracellular $\mathrm{Ca}^{2+}$ in both G418-treated and NT parasites.

\section{Acidification of trophozoite $\mathrm{pH}_{\mathrm{i}}$}

In other systems, increased endogenous ROS and intracellular $\mathrm{Ca}^{2+}$ are responsible for the loss of mitochondrial and endoplasmic reticulum membrane potentials, which subsequently decreases $\mathrm{pH}_{\mathrm{i}}$ levels (Demaurex et al., 2003). To evaluate the $\mathrm{pH}_{\mathrm{i}}$ as a consequence of G418-induced

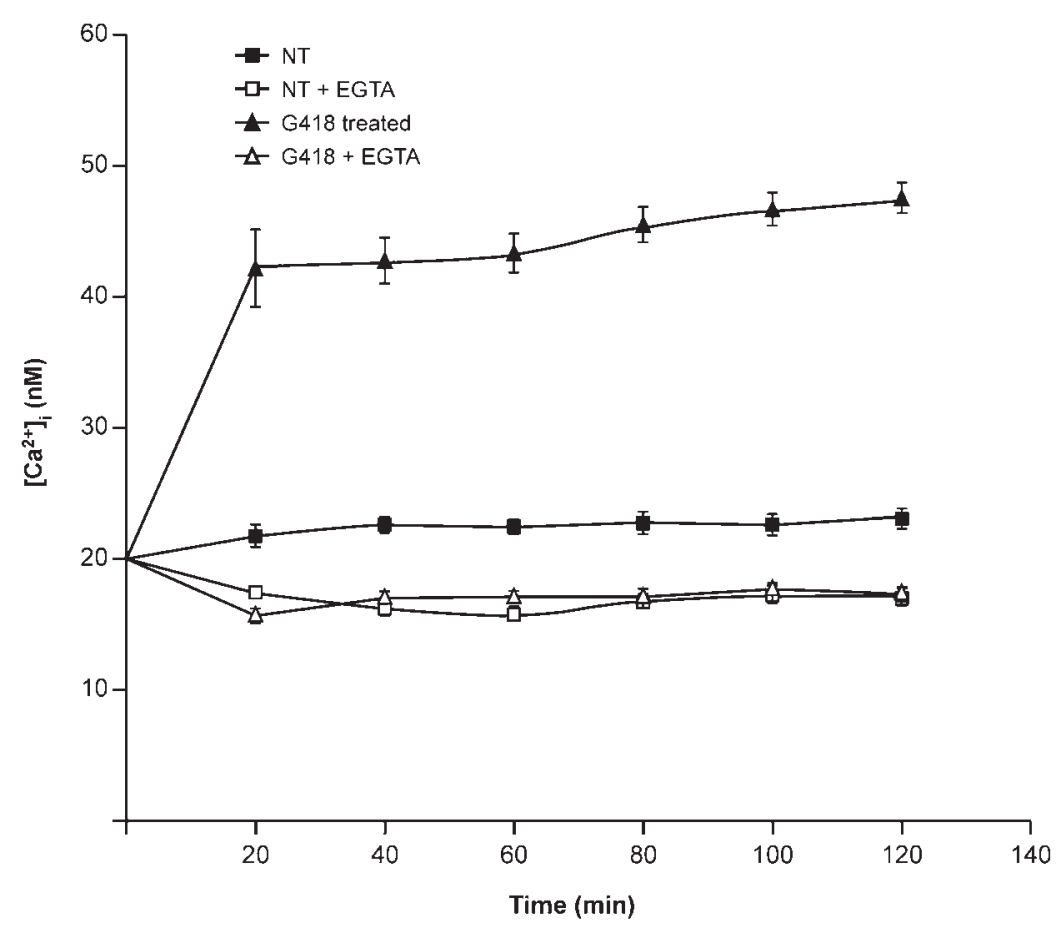

Fig. 6. Measurement of $\left[\mathrm{Ca}^{2+}\right]_{i} \cdot \mathrm{Ca}^{2+}$ concentrations were evaluated by fluorimetry using Fura-2/AM dye in NT ( $\mathbf{\square})$ or G418-treated ( $\mathbf{A})$ trophozoites. As an internal control, the $\mathrm{Ca}^{2+}$ chelator EGTA was used in NT ( $\square$ ) or G418treated trophozoites $(\triangle)$. 
PCD, a fluorescence method was utilized. Trophozoites were loaded with an acetomethyl ester derivative of BCECF, a dye whose fluorescence emission is sensitive to $\mathrm{pH}_{\mathrm{i}}$ variations. The excitation wavelengths were 440 and $490 \mathrm{~nm}$, and the emission was recorded at $535 \mathrm{~nm}$. The $\mathrm{pH}_{\mathrm{i}}$ of treated and NT parasites was recorded at $\mathrm{pH} 6.8$. The $\mathrm{pH}_{\mathrm{i}}$ of NT trophozoites remained constant at 7.8 over the incubation period. In contrast, a significant decrease in $\mathrm{pH}_{\mathrm{i}}$, from 7.8 to 6.0 , was observed after $3 \mathrm{~h}$ of $\mathrm{G} 418$ incubation (Fig. 7). These results indicate that the $\mathrm{pH}_{\mathrm{i}}$ of trophozoites undergoing PCD is more acidic than that of NT trophozoites.

\section{DISCUSSION}

It has been assumed that apoptosis, a form of PCD, was developed by multicellular organisms to regulate growth and development (Jacobson et al., 1997). However, recent reports have indicated that PCD also occurs in some species of unicellular organisms, including bacteria (Sat et al., 2001), yeast (Madeo et al., 1999), D. discoideum (Cornillon et al., 1994), and several protozoa such as $P$. gatunense (Vardi et al., 1999), Eu. gracilis (Scheuerlein et al., 1995), Tet. thermophila (Christensen et al., 1995), trypanosomatids (Nguewa et al., 2004), Plasmodium (Al-Olayan et al., 2002) and Blastocystis hominis (Nasirudeen et al., 2004). Evidence for a cell-suicide pathway in unicellular organisms that is analogous to metazoan apoptosis strongly suggests that PCD confers evolutionary advantages upon micro-organisms, including (i) selection of the bestadapted individuals in response to environmental changes (Lee et al., 2002; Verma \& Dey, 2004), (ii) regulation of the competition of parasites for limited resources in the gut or within the host (Dale et al., 1995), (iii) regulation of the cell cycle and cell differentiation (Hesse et al., 1995), and (iv) selection of specific parasitic forms, as non-infectious forms do not contribute to perpetuation of the parasite and might compete with the infectious parasites for available nutrients (Welburn et al., 1997). Some pathogens that infect mammalian hosts have developed mechanisms to repress programmed death in the cells required for pathogen replication or persistence, as well as mechanisms to induce programmed death in immune cells that may target the infected cell for destruction (Williams, 1994). These mechanisms not only favour immune evasion (Ameisen et al., 1994) but also might allow the growth of pathogens in host cells through uptake of apoptotic cells (Freire-de-Lima et al., 2000).

Seydel \& Stanley (1998) and Huston et al. (2003) demonstrated that E. histolytica trophozoites kill host cells by inducing apoptosis followed by phagocytic cell clearance, suggesting that this mechanism may limit inflammation and enable amoebae to evade the host immune response. Recently, Ramos et al. (2007) reported the in vitro induction of apoptosis in trophozoites after treatment with nitric oxide species. Taking into consideration the putative role of programmed death in the host-amoeba relationship, the present study investigated the induction of PCD in E. histolytica in response to an undesirable external stimulus, the exposure of trophozoites to the aminoglycoside antibiotic G418. G418 induces apoptosis in kidney cells (Jin et al., 2004) and in ear sensory hair cells (Matsui et al., 2004) by a caspase-3-dependent mechanism, and in T. cruzi (Billaut-Mulot et al., 1996) by an unknown mechanism.

In E. histolytica trophozoites, G418 caused a reduction in cell size and shrinkage of the cytoplasm, two of the most reliable morphological criteria for defining PCD (Huppertz et al., 1999). Flow cytometry and electron microscopy were employed to examine key ultrastructural features. Flow cytometry analysis showed that the decrease in cell size is

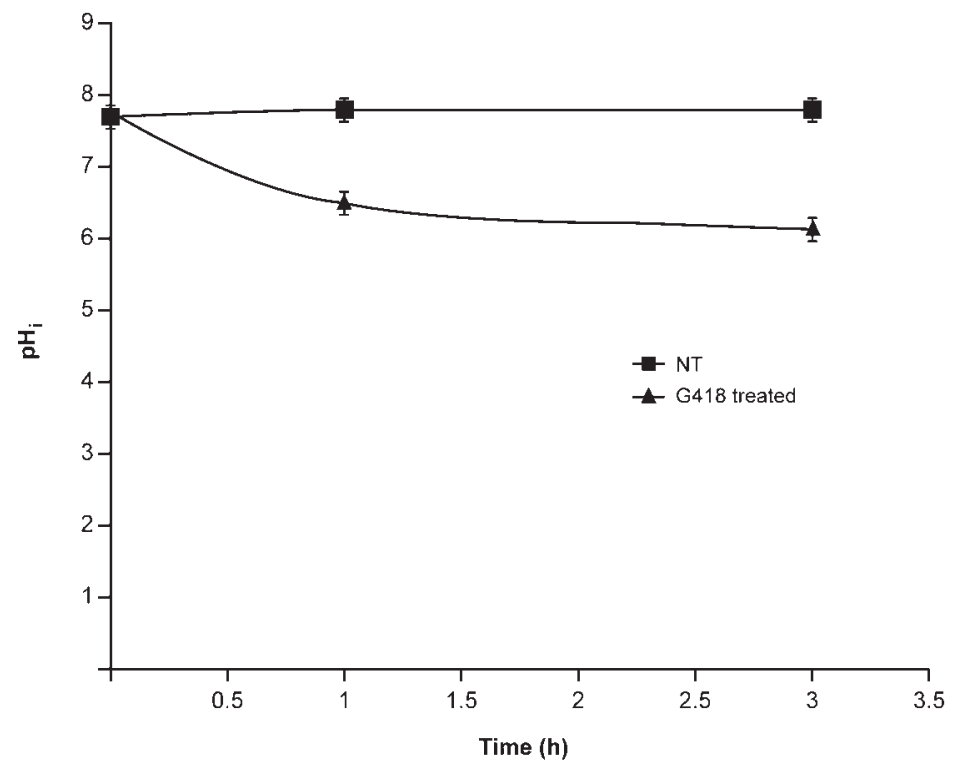

Fig. 7. Representative tracing of $\mathrm{pH}_{\mathrm{i}}$ changes after PCD induction. The kinetics of $\mathrm{pH}_{\mathrm{i}}$ was examined in NT ( $\boldsymbol{\square})$ or G418-treated ( $\boldsymbol{\Delta}$ ) trophozoites by using the fluorescent dye BCECF. 
accompanied by an increase in cell granularity, suggesting that vacuolization may also be related to cell death. Transmission electron micrographs of PCD-induced trophozoites confirmed the characteristics of the PCD process: cell shrinkage with an increased number and size of vacuoles, nuclear condensation, chromatin fragmentation, and, importantly, preservation of trophozoite cell-membrane integrity. Vacuolization has been reported in PCD of Caenorhabditis elegans (Robertson \& Thomson, 1982), D. discoideum (Cornillon et al., 1994), and some types of higher eukaryote cells (Wyllie et al., 1980; Clarke, 1990). During apoptosis, early ultrastructural nuclear lesions at a high level of chromatin organization lead to the appearance of large DNA fragments (300 and/or $50 \mathrm{~kb}$ ) revealed by PFGE (Walker et al., 1991; Tomei et al., 1993). This is often followed by lower-level DNA fragmentation (Wyllie, 1980), resulting in a gel electrophoresis ladder pattern of DNA fragments of $180-200 \mathrm{bp}$ and multiples thereof. In the present study, an obvious DNA fragmentation ladder could not be detected by gel electrophoresis analysis. Instead, a smear of degraded DNA and faint ladder bands were observed. However, DNA condensation and cleavage without disintegration of the cellular membrane were observed by transmission electron microscopy.

The highly sensitive TUNEL technique confirmed that an intracellular suicide program, rather than a necrotic process, is triggered in trophozoites during incubation with the antibiotic G418. TUNEL detects 3' OH groups at the ends of single- and double-stranded DNA breaks, whereas DNA cleavage in early necrosis is characterized by selective generation of $5^{\prime}$ overhangs but no $3^{\prime}$ overhangs (Didenko et al., 2003). Similar positive results have been obtained in E. histolytica by TUNEL and YOPRO-1 after induction with nitric oxide species (Ramos et al., 2007). However, some differences were observed in DNA fragmentation patterns: while the above authors reported four bands smaller than $500 \mathrm{bp}$, our results showed a more heterogeneous digestion pattern. The irregular nucleosomal organization of chromatin in E. histolytica reported by Torres-Guerrero et al. (1991) accords with our findings. Similarly, $D$. discoideum PCD is not characterized by DNA laddering (Cornillon et al., 1994). Alternatively, there are some reports that indicate that DNA fragmentation cannot always be regarded as a hallmark of apoptosis, as certain cells display morphological and biochemical features of apoptosis without a typical ladder-like DNA fragmentation (Collins et al., 1992; Howell \& Martz, 1987; Barbieri et al., 1992; Mesner et al., 1992; Falcieri et al., 1993; Vaux et al., 1994; Hirata et al., 1998).

We searched by in silico analysis for the presence of a putative caspase-like protein in the E. histolytica genome (TIGR 9712) (data not shown). The results did not show any matches that suggested the presence of a caspase-like protein, although the parasite contains 50 cysteine protease genes (Bruchhaus et al., 2003; Tillack et al., 2007). Ramos et al. (2007) have clearly demonstrated that E-64, a specific cysteine protease inhibitor, efficiently blocks E. histolytica cysteine protease activity. Thus, we decided to investigate the effect of E-64 on one of the most important features of PCD, DNA alteration. We showed that E-64 abolishes DNA degradation, as demonstrated by gel electrophoresis, TUNEL and electron microscopy ultrastructure, strongly suggesting that at least one of the cysteine proteases reported participates in G418-induced PCD. Our results contrast with those published by Ramos et al. (2007), in which the authors speculate that nitric oxide species induce a cysteine protease-independent apoptosis. This affirmation was based on the fact that E-64 treatment failed to abolish the death of trophozoites; however, no experiments were carried out to determine the effects with respect to the morphological and molecular characteristics of PCD.

In the early stages of eukaryote apoptosis, cells externalize PS, while maintaining membrane integrity (Gatti et al., 1998). As evidenced by electron microscopy, E. histolytica trophozoites induced to undergo PCD maintain membrane integrity, although annexin V-FITC failed to detect PS in the outer leaflet of the plasma membrane of NT or G418treated trophozoites. Aley et al. (1980) reported that PS makes up less than $10 \%$ of total membrane lipids in the plasma membrane of E. histolytica trophozoites. Martin et al. (1993) did not detect PS as a constituent of the E. histolytica plasma membrane by using ${ }^{31} \mathrm{P}-\mathrm{NMR}$ spectroscopy. They reported that the major phospholipids in whole amoebic extracts were phosphatidylcholine and two phosphatidylethanolamine species. Taking these findings into consideration, the results obtained here suggest three possibilities: (i) the abundance of PS is insufficient for detection by the method used here, (ii) the E. histolytica plasma membrane does not contain PS, or (iii) PS interacts with other membrane components that block its interaction with annexin $\mathrm{V}$.

In a typical apoptotic process, cell shrinkage is due to loss of cytoplasmic fluids and to the denaturation of proteins (Huppertz et al., 1999), producing characteristic biochemical features. It has been proposed that the generation of ROS inside cells causes an increase in the level of lipid peroxidation (Sen et al., 2004b). Lipid peroxidation decreases membrane fluidity and increases the leakiness of the membrane, leading to complete loss of cytoplasmic fluids and membrane integrity (Halliwell \& Gutteridge, 1989). This, in turn, causes a decrease in $\mathrm{K}_{\mathrm{i}}^{+}$and an increase in intracellular $\mathrm{Ca}^{2+}$ levels. The present study showed that E. histolytica PCD induced by G418 was accompanied by twofold increased intracellular ROS levels. Several studies (Kroemer \& Reed, 2000) support the hypothesis that disruption of membrane potential is an irreversible commitment to cell death. Most cells achieve and maintain balance of osmotic pressure through continuous activity of the $\mathrm{Na}^{+}-\mathrm{K}^{+}$ATPase pump, which creates and maintains an intracellular environment high in $\mathrm{K}^{+}$and low in $\mathrm{Na}^{+}$. It has been proposed that ROS inactivate the ATPase pump with the subsequent movement of ions (specifically $\mathrm{K}^{+}$) out of the cell, resulting in 
Table 1. Characteristics of PCD in unicellular organisms

Abbreviations: -, absence; +, presence; ND, not determined.

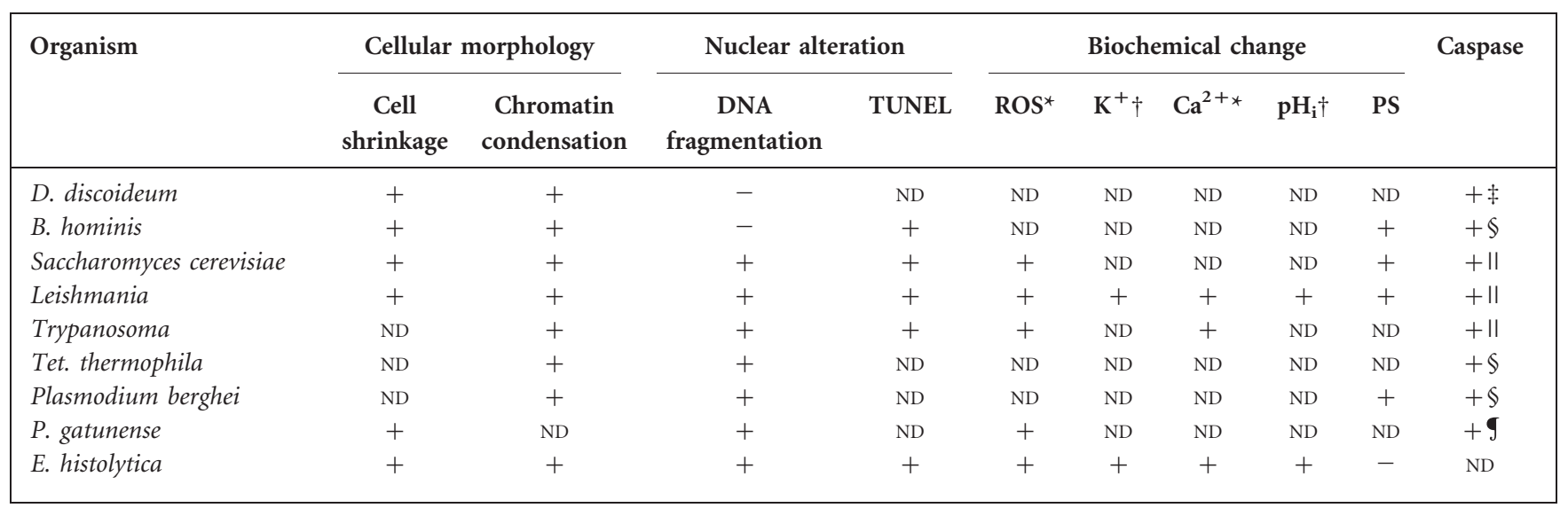

${ }^{\star}$ Increase.

$\dagger$ Decrease.

$\ddagger$ Paracaspase.

$\$$ Caspase-like.

IIMetacaspase.

Cysteine protease.

the loss of cell volume during apoptosis (Bortner et al., 1997). Our flow-cytometry results revealed that $\mathrm{K}_{\mathrm{i}}^{+}$levels decreased by more than $90 \%$ in the G418-treated trophozoites compared with NT trophozoites. Additionally, oxidative stress causes increased cytosolic $\mathrm{Ca}^{2+}$ levels, another common feature of apoptosis (Jiang et al., 1994). Our results showed a significant increase in the $\left[\mathrm{Ca}^{2+}\right]_{\mathrm{i}}$ in PCD-induced trophozoites, suggesting that $\mathrm{Ca}^{2+}$ has a pivotal role in this process in E. histolytica. $\mathrm{Ca}^{2+}$ is necessary for the activation of different enzymes, including cysteine proteases, that participate in PCD (Tagliarino et al., 2001). Finally, it has been suggested that immediately after the loss of the membrane potential, protons are released into the cytosol, thus contributing to intracellular acidification (Facompre et al., 2001). pH changes modulate the apoptotic responsiveness of the cell, and also amplify the apoptotic program by regulating enzymic activities (Matsuyama et al., 2000). As a consequence of the overproduction of ROS and the loss of $\mathrm{K}_{\mathrm{i}}^{+}$, a diminished $\mathrm{pH}_{\mathrm{i}}$ was observed for PCD-induced trophozoites.

In conclusion, the present study demonstrates, for what is believed to be the first time, PCD in E. histolytica induced by an external drug stimulus. This process is orchestrated by coordinated alterations in intracellular ion fluxes and subsequent morphological changes and ultrastructural alterations in DNA that are analogous to the events observed during PCD in other organisms (Table 1). Work currently in progress will allow us to determine the molecular components and steps involved in this intricate process, and also how this mechanism of cell death can be induced by other drugs. This knowledge will provide new insights into the host-parasite relationship and potential molecular targets for drug design.

\section{ACKNOWLEDGEMENTS}

This work was supported by CONACYT assistance given to D. G.P.I. The authors gratefully acknowledge Angelica Silva-Olivares for excellent technical assistance in transmission electron microscopy, and we express our gratitude to Alfredo Padilla Barberi for graphical design.

\section{REFERENCES}

Al-Olayan, E. M., Williams, G. T. \& Hurd, H. (2002). Apoptosis in the malaria protozoan, Plasmodium berghei: a possible mechanism for limiting intensity of infection in the mosquito. Int J Parasitol 32, 1133-1143.

Aley, S. B., Scott, W. A. \& Cohn, Z. A. (1980). Plasma membrane of Entamoeba histolytica. J Exp Med 152, 391-404.

Ameisen, J. C., Estaquier, J. \& Idziorek, T. (1994). From AIDS to parasite infection: pathogen-mediated subversion of programmed cell death as a mechanism for immune dysregulation. Immunol Rev 142, 9-51.

Barbieri, D., Troiano, L., Grassilli, E., Agnesini, C., Cristofalo, E. A., Monti, D., Capri, M., Cossarizza, A. \& Franceschi, C. (1992). Inhibition of apoptosis by zinc: a reappraisal. Biochem Biophys Res Commun 187, 1256-1261.

Berninghausen, O. \& Leippe, M. (1997). Necrosis versus apoptosis as the mechanism of target cell death induced by Entamoeba histolytica. Infect Immun 65, 3615-3621.

Billaut-Mulot, O., Fernandez-Gomez, R., Loyens, M. \& Ouaissis, A. (1996). Trypanosoma cruzi elongation factor $1-\alpha$ : nuclear localization in parasites undergoing apoptosis. Gene 174, 19-26. 
Bortner, C. D., Hughes, F. M., Jr \& Cidlowski, J. A. (1997). A primary role for $\mathrm{K}^{+}$and $\mathrm{Na}^{+}$efflux in the activation of apoptosis. J Biol Chem 272, 32436-32442.

Bruchhaus, I., Loftus, B. J., Hall, N. \& Tannich, E. (2003). The intestinal protozoan parasite Entamoeba histolytica contains 20 cysteine protease genes, of which only a small subset is expressed during in vitro cultivation. Eukaryot Cell 2, 501-509.

Chen, G., Branton, P. E. \& Shore, G. C. (1995). Induction of p53independent apoptosis by hygromycin B: suppression by Bcl-2 and adenovirus E1B 19-kDa protein. Exp Cell Res 221, 55-59.

Christensen, S. T., Wheatley, D. N., Rasmussen, M. I. \& Rasmussen, L. (1995). Mechanisms controlling death, survival and proliferation in a model unicellular eukaryote Tetrahymena thermophila. Cell Death Differ 2, 301-308.

Clarke, P. G. H. (1990). Developmental cell death: morphological diversity and multiple mechanisms. Anat Embryol (Berl) 181, 195-213.

Collins, R. J., Harmon, B. V., Gobe, G. C. \& Kerr, J. F. R. (1992). Internucleosomal DNA cleavage should not be the sole criterion for identifying apoptosis. Int J Radiat Biol 61, 451-453.

Cornillon, S., Foa, C., Davoust, J., Buonavista, N. \& Gross, J. D. (1994). Programmed cell death in Dictyostelium. J Cell Sci 107, 2691-2704.

Dale, C., Welburn, S. C., Maudlin, I. \& Milligan, P. J. M. (1995). The kinetics of maturation of trypanosome infections in tsetse. Parasitology 111, 187-191.

Demaurex, N., Frieden, M. \& Arnaudeau, S. (2003). ER calcium and ER chaperones: new players in apoptosis? In Calreticulin, 2nd edn, pp. 134142. Edited by P. Eggleton \& M. Michalak. Austin, TX: Eurekah.

Diamond, L. S., Harlow, D. R. \& Cunnick, C. C. (1978). A new medium for axenic cultivation of Entamoeba histolytica and other Entamoeba. Trans $R$ Soc Trop Med Hyg 72, 431-432.

Didenko, V. V., Ngo, H. \& Baskin, D. S. (2003). Early necrotic DNA degradation: presence of blunt-ended DNA breaks, $3^{\prime}$ and $5^{\prime}$ overhangs in apoptosis, but only $5^{\prime}$ overhangs in early necrosis. Am J Pathol 162, 1571-1578.

Espinosa-Cantellano, M. \& Martínez-Palomo, A. (2000). Pathogenesis of intestinal amebiasis: from molecules to disease. Clin Microbiol Rev 13, 318-331.

Facompre, M., Goossens, J. F. \& Bailly, C. (2001). Apoptotic response of HL-60 human leukemia cells to the antitumor drug NB-506, a glycosylated indolocarbazole inhibitor of topoisomerase 1. Biochem Pharmacol 61, 299-310.

Falcieri, E., Martelli, A. M., Bareggi, R., Cataldi, A. \& Cocco, L. (1993). The protein kinase inhibitor staurosporine induces morphological changes typical of apoptosis in MOLT-4 cells without concomitant DNA fragmentation. Biochem Biophys Res Commun 193, 19-25.

Freire-de-Lima, C. G., Nascimento, D. O., Soares, M. B. P., Bozza, P. T., Castro-Faria-Neto, H. C., de Mello, F. G., DosReisand, G. A. \& Lopes, M. F. (2000). Uptake of apoptotic cells drives the growth of a pathogenic trypanosome in macrophages. Nature 403, 199-203.

Gatti, R., Belletti, S., Orlandini, G., Bussolati, O., Dall'Asta, V. \& Gazzola, G. C. (1998). Comparison of Annexin V and Calcein-AM as early vital markers of apoptosis in adherent cells by confocal laser microscopy. J Histochem Cytochem 46, 895-900.

Gómez, C., Pérez, D. G., López-Bayghens, E. \& Orozco, E. (1998). Transcriptional analysis of the EhPgp1 promoter of Entamoeba histolytica multidrug-resistant mutant. J Biol Chem 273, 7277-7284.

Grynkiewicz, G., Poenie, M. \& Tsien, R. Y. (1985). A new generation of $\mathrm{Ca}^{2+}$ indicators with greatly improved fluorescence properties. J Biol Chem 260, 3440-3450.

Halliwell, B. \& Gutteridge, J. M. C. (1989). Free Radicals in Biology and Medicine, 2nd edn. Oxford: Clarendon Press.
Hawley, T. S. \& Hawley, R. G. (2004). Methods in Molecular Biology: Flow Cytometry Protocols, 2nd edn. Totowa, NJ: Humana Press.

Hesse, F., Selzer, P. M., Muhlstadt, K. \& Duszenko, M. (1995). A novel cultivation technique for long-term maintenance of bloodstream form trypanosomes in vitro. Mol Biochem Parasitol 70, 157-166.

Hirata, H., Hibasami, H., Yoshida, T., Morita, A., Ohkaya, S., Matsumoto, M., Sasaki, H. \& Uchida, A. (1998). Differentiation and apoptosis without DNA fragmentation in cultured Schwann cells derived from wallerian-degenerated nerve. Apoptosis 3, 353-360.

Howell, D. M. \& Martz, E. (1987). The degree of CTL-induced DNA solubilization is not determined by the human vs mouse origin of the target cell. J Immunol 138, 3695-3698.

Huppertz, B., Frank, H. G. \& Kaufmann, P. (1999). The apoptosis cascade - morphological and inmunohistochemical methods for its visualization. Anat Embryol (Berl) 200, 1-18.

Huston, C. D., Boettner, D. R., Miller-Sims, V. \& Petri, W. A. J. (2003). Apoptotic killing and phagocytosis of host cells by the parasite Entamoeba histolytica. Infect Immun 71, 964-972.

Jacobson, M. D., Weil, M. \& Raff, M. C. (1997). Programmed cell death in animal development. Cell 88, 347-354.

Jiang, S., Chow, S. C., Nicotera, P. \& Orrenius, S. (1994). Intracellular $\mathrm{Ca}^{2+}$ signals activate apoptosis in thymocytes: studies using the $\mathrm{Ca}^{2+}$-ATPase inhibitor thapsigargin. Exp Cell Res 212, 84-92.

Jin, Q. H., Zhao, B. \& Zhang, X. J. (2004). Cytochrome $c$ release and endoplasmic reticulum stress are involved in caspase-dependent apoptosis induced by G418. Cell Mol Life Sci 61, 1816-1825.

Kroemer, G. \& Reed, J. C. (2000). Mitochondrial control of cell death. Nat Med 6, 513-519.

Lee, N., Bertholet, S., Debrabant, A., Muller, J., Duncan, R. \& Nakhasi, H. L. (2002). Programmed cell death in the unicellular protozoan parasite Leishmania. Cell Death Differ 9, 53-64.

Lewis, K. (2000). Programmed death in bacteria. Microbiol Mol Biol Rev 64, 503-514.

Madeo, F., Frohlich, E., Ligr, M., Grey, M., Sigrist, S. J., Wolf, D. H. \& Frohlich, K. U. (1999). Oxygen stress: a regulator of apoptosis in yeast. J Cell Biol 145, 757-767.

Martin, J. B., Bakker-Grunwald, T. \& Klein, G. (1993). ${ }^{31} \mathrm{P}-\mathrm{NMR}$ analysis of Entamoeba histolytica. Occurrence of high amounts of two inositol phosphates. Eur J Biochem 214, 711-718.

Matsui, J. I., Gale, J. E. \& Warchol, M. E. (2004). Critical signaling events during the aminoglycoside-induced death of sensory hair cells in vitro. J Neurobiol 61, 250-266.

Matsuyama, S., Llopis, J., Deveraux, Q. L., Tsien, R. \& Reed, J. C. (2000). Changes in intramitochondrial and cytosolic pH: early events that modulate caspase activation during apoptosis. Nat Cell Biol 2, 318-325.

Mesner, P. W., Winters, T. R. \& Green, S. H. (1992). Nerve growth factor withdrawal-induced cell death in neuronal PC12 cells resembles that in sympathetic neurons. J Cell Biol 119, 1669-1680.

Nasirudeen, A. M. A., Hian, Y. E., Singh, M. \& Tan, K. S. W. (2004). Metronidazole induces programmed cell death in the protozoan parasite Blastocystis hominis. Microbiology 150, 33-43.

Nguewa, P. A., Fuentes, M. A., Valladares, B., Alonso, C. \& Pérez, J. M. (2004). Programmed cell death in trypanosomatids: a way to maximize their biological fitness? Trends Parasitol 20, 375-380.

Ragland, B. D., Ashley, L. S., Vaux, D. L. \& Petri, W. A., Jr (1994). Entamoeba histolytica: target cells killed by trophozoites undergo DNA fragmentation which is not blocked by Bcl-2. Exp Parasitol 79, 460-467. 
Ramos, E., Olivos-García, A., Nequiz, M., Saavedra, E., Tello, E., Saralegui, A., Montfort, I. \& Pérez Tamayo, R. (2007). Entamoeba histolytica: apoptosis induced in vitro by nitric oxide species. Exp Parasitol 116, , 257-265.

Robertson, A. M. G. \& Thomson, J. N. (1982). Morphology of programmed cell death in the ventral nerve cord of Caenorhabditis elegans larvae. J Embryol Exp Morphol 67, 89-100.

Sat, B., Hazan, R., Fisher, T., Khaner, H., Glaser, G. \& EngelbergKulka, H. (2001). Programmed cell death in Escherichia coli: some antibiotics can trigger mazEF lethality. J Bacteriol 183, 2041-2045.

Scheuerlein, R., Treml, S., Thar, B., Tirlapur, U. K. \& Hader, D. P. (1995). Evidence for UV-B-induced DNA degradation in Euglena gracilis mediated by activation of metal-dependent nucleases. J Photochem Photobiol B 31, 113-123.

Sen, N., Das, B. B., Ganguly, A., Mukherjee, T., Bandyopadhyay, S. \& Majumder, H. K. (2004a). Camptothecin-induced imbalance in intracellular cation homeostasis regulates programmed cell death in unicellular hemoflagellate Leishmania donovani. J Biol Chem 279, 52366-52375.

Sen, N., Das, B. B., Ganguly, A., Mukherjee, T., Tripathi, G., Bandyopadhyay, S., Rakshit, S., Sen, T. \& Majumder, H. K. (2004b). Camptothecin induced mitochondrial dysfunction leading to programmed cell death in unicellular hemoflagellate Leishmania donovani. Cell Death Differ 11, 924-936.

Seydel, K. B. \& Stanley, S. L., Jr (1998). Entamoeba histolytica induces host cell death in amebic liver abscess by a non-Fas-dependent, nontumor necrosis factor alpha-dependent pathway of apoptosis. Infect Immun 66, 2980-2983.

Tagliarino, C., Pink, J. J., Dubyak, G. R., Nieminen, A. L. \& Boothman, D. A. (2001). Calcium is a key signaling molecule in $\beta$-lapachonemediated cell death. J Biol Chem 276, 19150-19159.

Tandogan, B. \& Ulusu, N. N. (2005). Importance of calcium. Tr J Med Sci 35, 197-201.

Tillack, M., Biller, L., Irmer, H., Freitas, M., Gomes, M., Tannich, E. \& Bruchhaus, I. (2007). The Entamoeba histolytica genome: primary structure and expression of proteolytic enzymes. BMC Genomics 8, 170.

Tomei, L. D., Shapiro, J. P. \& Cope, F. O. (1993). Apoptosis in C3H/ 10T1/2 mouse embryonic cells: evidence for internucleosomal DNA modification in the absence of double-strand cleavage. Proc Natl Acad Sci U S A 90, 853-857.

Torres-Guerrero, H., Peattie, D. A. \& Meza, I. (1991). Chromatin organization in Entamoeba histolytica. Mol Biochem Parasitol 45, 121-130.

Vardi, A., Berman-Frank, I., Rozenberg, T., Hadas, O., Kaplan, A. \& Levine, A. (1999). Programmed cell death of the dinoflagellate Peridinium gatunense is mediated by $\mathrm{CO}_{2}$ limitation and oxidative stress. Curr Biol 9, 1061-1064.

Vaux, D. L., Haecker, G. \& Strasser, A. (1994). An evolutionary perspective on apoptosis. Cell 76, 777-779.

Verma, N. K. \& Dey, Ch. S. (2004). Possible mechanism of miltefosine-mediated death of Leishmania donovani. Antimicrob Agents Chemother 48, 3010-3015.

Walker, P. R., Smith, C., Youdale, T., Leblanc, J., Whitfield, J. F. \& Sikorska, M. (1991). Topoisomerase II reactive chemotherapeutic drugs induce apoptosis in thymocytes. Cancer Res 51, 1078-1085.

Wanderley, J. L., Benjamin, A., Real, F., Bonomo, A., Moreira, M. E. \& Barcinski, M. A. (2005). Apoptotic mimicry: an altruistic behavior in host/Leishmania interplay. Braz J Med Biol Res 38, 807-812.

Welburn, S. C., Barcinski, M. A. \& Williams, G. T. (1997). Programmed cell death in trypanosomatids. Parasitol Today 13, 22-26.

Williams, G. T. (1994). Programmed cell death - a fundamental protective response to pathogens. Trends Microbiol 2, 463-464.

Wyllie, A. H. (1980). Glucocorticoid-induced thymocyte apoptosis is associated with endogenous endonuclease activation. Nature 284, 555-556.

Wyllie, A. H., Kerr, J. F. R. \& Currie, A. R. (1980). Cell death: the significance of apoptosis. Int Rev Cytol 68, 251-306.

Edited by: J. Tachezy 